\title{
Optimized Research on Capital Structure of Listed Companies in Chinese Real Estate Industry
}

\author{
Xinling $\mathrm{Du}^{1, \mathrm{a}}$ and Yin Luo $\mathrm{o}^{1, \mathrm{~b}^{*}}$ \\ 1Beijing Normal University Zhuhai Campus, Zhuhai 519087, China \\ ${ }^{*}$ Corresponding Author, Luo Yin

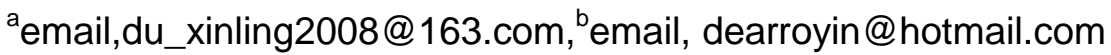

Keywords: Listed Companies; Real Estate; Capital Structure; Listed Companies

\begin{abstract}
The real estate industry is the pillar industry of national economy, and its healthy development can promote the prosperity of finance, construction and manufacturing. From the perspective of capital structure, combined with situation of Chinese real estate listed companies and using the regression analysis, the paper found out related factors influencing the capital structure of real estate companies, and analyzed the influencing factors to capital structure of real estate companies from enterprise profitability, debt paying ability, enterprise size, ownership structure, income tax and enterprise growth; the result shows that the enterprise scale, debt paying ability, and ownership structure have a significant influence on the capital structure of real estate listed companies, but profitability, business growth and income tax have little impact on the capital structure.
\end{abstract}

\section{Introduction}

Real estate industry is an important part of Chinese economy, and has an important effect on its economic growth. However, for many real estate companies, the unreasonable capital structure, poor management level and declining performance lead to capital turnover problems. Capital structure refers to the proportion of debt and equity in financial structure, and it is of great importance for enterprise operation and development to maintain good capital structure. The financing channel for real estate enterprises is single because of the high independence on national economic environment and policy. In this background, capital structure optimization for Chinese real estate enterprise has certain significance.

\section{Theoretical Analysis and Research Assumption}

Based on the researches on domestic and foreign capital structure, from the angle of enterprise value assessment, the paper proposed the following six assumptions on influencing factors:

The enterprise profitability and capital structure are negatively related. Corporate profits increase when the profitability is improved; the internal financing through retained earnings of its own can be chosen for enterprise financing, and the corresponding external demand for equity financing and bond financing will decrease, which reduce the assets and liabilities levels.

Enterprise debt paying ability and capital structure are negatively related. Debt paying 
ability reflects the enterprise comprehensive ability. In addition to knowing the possibility of wining more profits, enterprises need to know the possibility of repaying the debt timely. Enterprises with good comprehensive ability can choose more financing ways, such as equity financing, in which the assets and liabilities levels are relatively low.

The enterprise scale and capital structure are positively related. Large-scale enterprises often tend to diversified operation or vertical integration development, which can appropriately decentralize management risk and bring more stable benefits for enterprise. However, bigger scale requires more funds for supplement, so the assets and liabilities level will increase. Bigger scale enterprises have stable operation and better credit, which is good for financing.

The enterprise growth and capital structure are positively related. Generally, in the growth period, enterprises requires massive funds; due to the limited operating surplus, enterprises require more external financing rather than internal financing for expansion. Enterprises with good growth require more funds for expansion, and more channels for funds, which lead to higher debt rate.

The enterprise equity structure and capital structure are related. Equity structure refers to the proportion of legal person share, state owned share and tradable share in the capital stock. The proportion of state owned share and legal person share is lower as higher proportion affect the circulation of shares. Enterprises with higher proportion of state owned share are generally controlled by the state, intervened by the government in operation, and have higher debt rates.

\section{Index Design and Variable Identification}

Index design. The first class indexes for analysis include enterprise profitability, debt paying ability, enterprise scale, enterprise growth, enterprise equity structure and tax revenue; the second class indexes and corresponding variables are shown in table 1.

Table 1 Indexes and variables

\begin{tabular}{l|l|l}
\hline First class indexes & Second class indexes & Variables \\
\hline \multirow{2}{*}{ Profitability } & Main operating business profit rate & $X_{1}$ \\
\cline { 2 - 3 } & Net assets profit & $X_{2}$ \\
\hline \multirow{2}{*}{ Debt paying ability } & Current ratio & $X_{3}$ \\
\cline { 2 - 3 } & Liquidity ratio & $X_{4}$ \\
\hline \multirow{2}{*}{ Enterprise growth } & Total enterprise assets & $X_{5}$ \\
\cline { 2 - 3 } & Main operating revenue & $X_{6}$ \\
\cline { 2 - 3 } & Main operating revenue growth rate & $X_{7}$ \\
\hline \multirow{2}{*}{$\begin{array}{l}\text { Enterprise equity } \\
\text { structure }\end{array}$} & $\begin{array}{l}\text { Percentage of tradable shares } \\
\text { (tradable shares number/total } \\
\text { capital shares) }\end{array}$ & $X_{9}$ \\
\hline Capital structure & Assets and liabilities rate & $Y$ \\
\hline
\end{tabular}

Explanatory variables. The explanatory variables refer to the variable that can affect capital structure. The explanatory variables are ${ }^{X_{1}}, X_{2}, X_{3}, X_{4}, X_{5}, X_{6}, X_{7}, X_{8}, X_{9}, X_{10}$, of which $X_{5}$ and $X_{6}$ are the logarithm of total enterprise assets and main operating revenue. 
Explained variable. The capital structure is reflected by total assets and liabilities rate, expressed by $Y$, namely $\mathrm{Y}=$ total liabilities/total assets.

\section{Sample Selection and Data Sources}

The principles of selecting samples in Chinese real estate listed companies are:

(1) Select the A-share and $\mathrm{H}$-share companies that are going public in Shanghai and Shenzhen stock market.

(2) Select the listed companies whose earnings in real estate are higher than half of the main operating revenue.

(3) Eliminate the listed companies with bad management condition, namely ST-share listed real estate enterprises.

There are 40 companies that meet the above three conditions; take the 40 companies as the sample, whose financial data are from Oriental wealth website in 2013.

\section{Modeling}

The paper established a multiple linear regression model by using the selected explanatory variables and explained variables:

$$
Y=\beta_{0}+\beta_{1} \cdot X_{1}+\beta_{2} \cdot X_{2}+\beta_{3} \cdot X_{3}+\cdots+\beta_{10} \cdot X_{10}+\varepsilon
$$

In the model, $X_{i}(i=1,2,3,4 \cdots n)$ is the influencing factors index; $\beta_{i}(i=1,2,3 \cdots n)$ is regression coefficient; $\varepsilon$ is random error.

\section{Empirical Analyses}

In order to exactly understand the influencing factors of capital structure, at the significance level of 0.05, the paper adopted SPSS and the statistical analysis software, in order to make multiple regression analysis above 10 variables, and confirmed the empirical evidence of affecting capital structure.

Table 2 Model Summary

\begin{tabular}{|c|c|c|c|c|}
\hline Model & $\mathrm{R}$ & $\mathrm{R}^{2}$ & Adjustment $\mathrm{R}^{2}$ & $\begin{array}{c}\text { Estimated error based on } \\
\text { standard }\end{array}$ \\
\hline 1 & $0.896^{\mathrm{a}}$ & 0.803 & 0.736 & 8.16900 \\
\hline
\end{tabular}

a. Predictive Variable: $X_{1}, X_{2}, X_{3}, X_{4}, X_{5}, X_{6}, X_{7}, X_{8}, X_{9}, X_{10}$, Constant

According to the empirical results in Table 2, R2 of the model after adjustment is 0.736 , with high degree of fitting, which means the linear correlation between explanatory variables and explained variables is relatively higher, and linear regression analysis can be made. 
Table 3 Anova ${ }^{\mathrm{b}}$

\begin{tabular}{|c|c|c|c|c|c|c|}
\hline \multicolumn{2}{|c|}{ Model } & $\begin{array}{c}\text { Quadratic } \\
\text { sum }\end{array}$ & df & $\begin{array}{c}\text { Mean } \\
\text { square }\end{array}$ & F & Sig. \\
\hline \multirow{3}{*}{1} & regression & 7912.410 & 10 & 791.241 & 11.857 & $0.000^{\mathrm{a}}$ \\
\cline { 2 - 7 } & residue & 1935.246 & 29 & 66.733 & & \\
\cline { 2 - 7 } & Total & 9847.656 & 39 & & & \\
\hline
\end{tabular}

a. Predictive Variable: $X_{1}, X_{2}, X_{3}, X_{4}, X_{5}, X_{6}, X_{7}, X_{8}, X_{9}, X_{10}$, constant

b. Dependent Variable: $Y$

According to Table 3, the $\mathrm{P}$ value, probability of relevant coefficients inspection, approximates to 0 , and significance test of regression equation can be made.

Table 4 Coefficients ${ }^{\mathrm{a}}$

\begin{tabular}{|c|c|c|c|c|c|c|}
\hline & \multirow[t]{2}{*}{ Model } & \multicolumn{2}{|c|}{$\begin{array}{l}\text { Unstandardized } \\
\text { Coefficients }\end{array}$} & \multirow{2}{*}{$\begin{array}{c}\text { Standardiz } \\
\text { ed } \\
\text { Coefficient } \\
\mathrm{s}\end{array}$} & \multirow[b]{2}{*}{$\mathrm{t}$} & \multirow[b]{2}{*}{ Sig. } \\
\hline & & B & $\begin{array}{l}\text { Std. } \\
\text { Error }\end{array}$ & & & \\
\hline 1 & $\begin{array}{c}\text { Constan } \\
\mathrm{t}\end{array}$ & 43.976 & 14.759 & & 2.980 & 0.006 \\
\hline & $X_{1}$ & 0.215 & 0.172 & 0.128 & 1.245 & 0.223 \\
\hline & $X_{2}$ & -0.138 & 0.181 & -0.080 & -0.760 & 0.453 \\
\hline & $X_{3}$ & -9.609 & 3.106 & -0.716 & -3.094 & 0.004 \\
\hline & $X_{4}$ & 6.181 & 6.040 & 0.205 & 1.023 & 0.315 \\
\hline & $X_{5}$ & 5.410 & 1.616 & 0.529 & 3.348 & 0.002 \\
\hline & $X_{6}$ & -1.117 & 1.120 & -0.125 & -0.997 & 0.327 \\
\hline & $X_{7}$ & 0.062 & 0.053 & 0.115 & 1.165 & 0.254 \\
\hline & $X_{8}$ & 0.007 & 0.011 & 0.052 & 0.573 & 0.571 \\
\hline & $X_{9}$ & 0.171 & 0.074 & 0.201 & 2.302 & 0.029 \\
\hline & $X_{10}$ & -0.165 & 0.106 & -0.166 & -1.552 & 0.132 \\
\hline
\end{tabular}

a. dependent variable: $Y$

Table 4 reflects the results of model coefficient estimation and inspection coefficient, only the $\mathrm{P}$ value of ${ }^{X_{3}}, X_{5}$ and $X_{9}$ is less than 0.05 in the 10 selected explanatory variables, which indicates that the correlation among variables is relatively obvious, and the correlation between the rest 7 indexes and assets and liabilities rate is not obvious.

Canonical correlation efficient of current ratio and assets and liabilities rate is -0.716; canonical correlation efficient of total enterprise assets and assets and liabilities rate is 0.529 ; canonical correlation efficient of tradable share proportion and assets and liabilities rate is 0.201 . Therefore, the model of influencing factors for enterprise capital structure is: 


$$
Y=43.976-0.716 X_{3}+0.529 X_{5}+0.201 X_{9}
$$

\section{Conclusion}

The empirical results verify the positive correlation between enterprise scale and assets and liabilities rate. From the realistic situation, in order to get financial support through bond financing and equity financing, enterprises need to be strictly reviewed by relevant institutions, and the enterprises with strong comprehensive ability are easy to get fund support. The most important financing channel for the Chinese real estate enterprises is bank loans, and banks tend to lend money to larger enterprises. Larger enterprises have more choices for financing than smaller enterprises as larger enterprises have strong in anti-risk ability, high management level, stable operating income and more reasonable capital structure.

The empirical results verify the negative correlation between debt paying ability and assets and liabilities rate. When the enterprise debt paying ability is poorer, there will be fewer choices for financing. Considering the factors such as refundment and risks, operators tend to choose equity financing. Good debt paying ability indicates more internal retained earnings, so more funds are required for internal financing; the enterprises get funds through internal financing.

The empirical results verify the positive correlation between share structure and assets and liabilities rate. Although the correlation between the two is low and certain effect on the capital structure of listed real estate companies from tradable share proportion, tradable share proportion is not the main factors influencing the capital structure of listed companies.

The empirical result shows that enterprise growth, profitability and revenue have no obvious correlation with capital structure. The Chinese listed real estate companies are mostly resources dependent rather than the company with efficiency. The market recognition to real estate development companies basically depends on the degree of resources possession; large proportion of resource possession has bigger opportunity in getting loans. In taxation, the income tax rate of Chinese enterprise is usually $25 \%$ of the total amount of profit, but the role of assets and liabilities rate in reducing tax burden is not played in the aspect of income tax.

In conclusion, enterprises need to improve the capital structure from total assets, debt paying ability and equity structure, and mobilize internal and external resources for enterprises to gain greater value, such as to control reasonable debt ratio, improve the debt structure, broaden financing channels, improve the level of enterprise management, etc. Finally, enterprises should formulate appropriate development strategies according to its own capital structure, and avoid one-sided pursuit of financing data optimization.

\section{References}

[1] Yu Shaolei, Li Xiaojian. Empirical Study on the Influence of Capital Structure to Enterprise Value - Take Listed Real Estate Companies as Examples [J]. Friends of Accounting, 2014, $15: 78-82$

[2] Xie Zhuojun, Ni Lei. Study on Influencing Factors of Capital Structure in Our Listed Real Estate Companies [J]. Journal of postgraduates in Central China Normal University, 2014, 01:146-150

[3] Zhang Qixiu, Shen Lu. Empirical Analysis on Influencing Factors of Real Estate Enterprise Capital Structure[J]. New Account, 2013， 09:7-9+14 
[4] Liu Xinshao. Study on Capital Structure Optimization of Sunshine Real Estate Co., Ltd [D]. Hunan University, 2013

[5] Tan Qinghong. Empirical Analysis on Influencing Factors of Capital Structure in Listed Real Estate Companies [J]. EnterpriseTechnology and Development, 2011, 11:74-77

[6] Xu Honghai, Guo Jiang. Analysis on Listed Enterprises Capital Structure Optimization [J]. Special Zone Economy, 2011，05:120-121

[7] Mao Zhemin. Empirical Analysis on Influencing Factors of Capital Structure in Listed Real Estate Companies [J]. Market Modernization, 2009, 18:80-81

[8] Gao Minghan. Study on Capital Structure Optimization in Listed Real Estate Companies [J]. Financial Community (Academic Ddition), 2014, 04:122-123

[9] Website of State Statistics Bureau www.stats.gov.cn

[10] Chinese Economic Information Network Statistical Database Website. http://db.cei.gov.cn/page/Default.aspx

[11] East Money Website. http://www.eastmoney.com. 